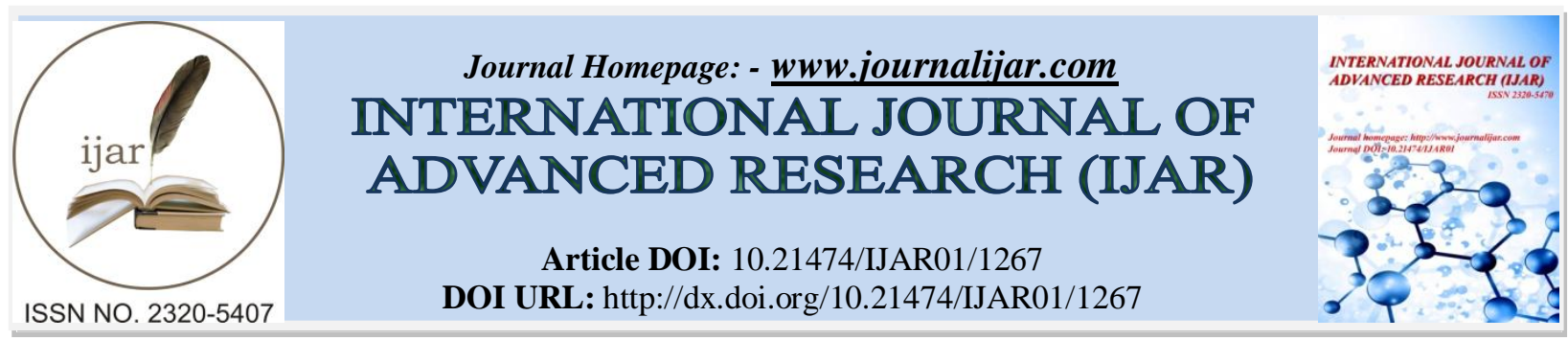

RESEARCH ARTICLE

\title{
TITLE OF PAPER: EVALUATION OF EFFICACY OF SHIROVASTHI IN THE MANAGEMENT OF PAKSHAGHATA: A PILOT STUDY.
}

\section{Dr. P. Sushma ${ }^{1}$ and Dr. Ch. Sadanandam ${ }^{2}$}

1. PG SCHOLAR, Pg dept of Panchakarma, Dr. BRKR. Govt. Ayurvedic College, Hyderabad, Telangana.

2. ASSOCIATE PROFESSOR, I/C HOD, Pg Dept of Panchakarma, Dr. BRKR. Govt. Ayurvedic College, Hyderabad, Telangana.

\section{Manuscript Info}

Manuscript History

Received: 16 June 2016

Final Accepted: 19 July 2016

Published: August 2016

Key words:-

Pakshaghata, shirovasthi, vata vyadhi, dhanvantaram tailam.

\section{Abstract}

Now a days the present day life is very fast, competitive so, patients also looking for immediate cure. Though number of techniques \& remedies are available most of people prefers Ayurveda only for Pakshaghata. The term Pakshaghata denotes a specific variety of Vatavyadhis it is characterized by impairment of sanghavaha \& chestavaha function. Pakshaghata is such a disease caused predominately by Vata dosha even though all the three doshas also take part besides its dushyas namely siras, snayu, dhamani, sandhi \& mamsa resulting into this disease.since the Shirovasthi selected for clinical trial is possessing the qualities of antagonists to the Pakshaghata. Sirovasthi particular for Pakshaghata is indicated by Sushruta. The gunas of Vatahara taila directly reach site of lesion of Pakshaghata I.e., Mastishka by shirovasthi. Tailam used is Dhanvantaram Tailam which is unique remedy for vata vyadhi. Both snehana swedana is done simultaneously in pakshaghata. For this study 9 patients satisfying the selection criteria were randomly selected from the OPD \& IPD of Panchakarma Department of Dr. B.R.K.R Govt. Ayurvedic College and Hospital, Erragadda, Hyderabad. The assessment of results was made on pre $\&$ post treatment data of subjective \& objective parameters of clinical study signs and symptoms of Pakshaghata taken as subjective \& objective parameters. Over all result of shirovasthi therapy is 78\% in Pakshaghata. By Observations it is noted that on walking it has shown $70 \%$, on lifting of arm at shoulder $94 \%$, on lifting of leg at hip joint $83 \%$, on loss of speech $76 \%$, on finger movement $65 \%$ improvement seen. On Tendon reflexes $76 \%$ and on muscle power it has shown $85 \%$ improvement. Good improvement in 4 patients, moderate improvement in 5 patients, no poor improvement is seen during study so, hence it is concluded from the study that the shirovasthi is statically highly significant.

Copy Right, IJAR, 2016,. All rights reserved. 


\title{
Introduction:-
}

Stroke is a Non-communicable disease of increasing socioeconomic importance in ageing populations. According to WHO, Stroke was the second commonest cause of worldwide mortality in 1990 and, the third commonest cause of mortality in more developed countries. Stroke is also a major cause of long-term disability and, has potentially enormous emotional and socioeconomic consequences for patients, their families, and health services. We know that $50 \%$ of Indian population is above the age group of 50yr \& one out of 10 suffer from vatavyadhi and majority of them suffer from pakshaghata. The incidence of Pakshaghata is alarming. It occurs mostly as complication of diabetes mellitus, hypertension. Hemiplegia is the outcome of stroke and its parallel to pakshaghata in Ayurveda. Without movements human being is just like a lifeless statue. This is exactly what occurs in case of Pakshaghata. Pakshaghata is one of the 80 vatavikaras, described in almost all ayurvedic literature. Vata is sole dosha for all the movements in the body and thus responsible for the disease. Pakshaghata is very common among vatavyadhi's. In Modern science it is treated with Anti thrombolytic, anti platelet drugs but success rate is very low; especially restoration of movements is difficult. Shirovasthi is best treatment to combat vata. Wherein Ayurvedic line of treatments are giving encouraging results.

Sushruta concept "tatra prageve sneha svedopapannam mruduve sodhanena samshodhya anuvasya asthapyacha....Akshepaka vidhanana upacharat. Here, we can see an elaborate description of different aspects of treatment along with routine type of treatment like sneha sweda, mrudu virechana. Sushruta mentions bala taila, shirovasthi, anutaila, abhyanga, salvana sweda as special treatment.

Aim \& Objectives: - To assess the effect of shirovasthi in pakshaghata.

\section{Materials and Methods:-}

Study Design: It was an open, randomized, preliminary clinical study.

Source of data:-Patients are selected from OPD \& IPD of Dr. B.R.K.R. Govt. Ayurvedic College \& Hospital, Hyderabad. Having classical signs \& symptoms of Pakshaghata as well as fulfilling inclusion \& exclusion criteria.

Sample size: Total 9 patients completed the treatment schedule.

Inclusion Criteria: Patients diagnosed as suffering from Pakshaghata, based on classical signs and symptoms of Pakshaghata were included in the study.

Exclusion Criteria: Patients below age 30 and more than 70years and the patients who are having chronicity of disease more than 6yr are excluded from this study.

Assessment Criteria: A Special research proforma was prepared for the study incorporating all the relevant points from both ayurvedic and modern views. Some Subjective parameters like walking, lifting or arm at shoulder, lifting of leg at hip joint, loss of speech, finger movement and some Objective parameters like Tendon reflexes, muscle power test. Each parameter was given grading.

\author{
Showing Grading of Subjective Parameters:- \\ I. Walking: \\ * Bed ridden -0 \\ * Walks with assistant - 1 \\ - Walks with stick wall - 2 \\ * Walks with slight support -3 \\ - Walks without support -4 \\ - Walks with speed - 5 \\ II. Lifting of arm at shoulder: \\ * No lifting -0 \\ - Upto $45^{\circ}-1$ \\ - Upto $90^{\circ}-2$ \\ - Upto $135^{\circ}-3$ \\ - Upto $180^{\circ}-4$
}




\section{Lifting of leg at hip joint:}

- No lifting -0

- Upto $45^{\circ}-1$

* Upto $90^{\circ}-2$

IV. Loss of Speech:

* Global aphasia -4

* Utter voice - 3

* Speak few words -2

- Speak with difficulty - 1

* Normal-0

V. Finger movement:

- No movement -0

* Slight movement-1

* Unable to hold the objects - 2

- Able to hold with less power -3

* Normal-4

Gradation of Objective parameters:-

I. Tendon reflexes:

* Absent -0

* Positive -1

- Brisk - 2

* Very brisk -3

* Clonus -4

\section{Muscle power grading:}

* No contractions -0

- Flicker or trace of contraction - 1

* Active movement with gravity elimination -2

* Active movement against gravity - 3

* Active movement against gravity and resistance -4

* Normal-5

Grouping of the results of Subjective \& Objective parameters were made as follows

$\%$ of relief of all symptoms is assessed below mentioned pattern.

- $0 \%-25 \%$ - no relief

- 25\%-50\% - mild relief

- 50\% - 75\% -moderate relief

- 75\%-100\%- marked relief.

\section{Drugs under trial:-}

* Dhanvantaram tailam

- Shirovasthi is a procedure in which the medicated oil is allowed to stay over the head for the prescribed time. It is one among the moordhataila. It is beneficial to do Shirovasthi after proper purificatory procedures. But in cases where shodana is not necessary it can be done directly.

\section{Materials required:-}

1. Rexin/leather $(75 \mathrm{~cm}$ X $20 \mathrm{~cm})-1$

2. Black gram flour $-200 \mathrm{~g}$

3. Taila -1.5 liters

4. Cotton ribbon $(120 \mathrm{~cm} \mathrm{X} 10 \mathrm{~cm})-2$ strips, moderately tough, clean and dry

5. Spoon -1

6. Vessel (2 liters) -1 
7. Large vessel- 1

8. Rasnadi choorna- $5 \mathrm{~g}$

9. Oil for abhyanga- $100 \mathrm{ml}$

10. Soft towel- 2

11. Hot waterbath-1

12. Armed chair of knee-height- 1

13. Attendent-2

\section{Pre operative procedure:-}

Shave the head completely. Do generalized abhyanga. Keep cotton cloth in both ears to prevent the entry of oil in to the ear. Bowel and bladder should be emptied.

\section{Procedure:-}

* The patient should be properly seated in an armed chair. The strip of cloth smeared with the paste of black gram flour is to be wound round the head $2 \mathrm{~cm}$ above the eye brows.

* It should be tight enough to prevent leaking of the oil, but not causing any discomfort. The rexin or leather should be fixed over the strap and the junctions are sealed with black gram paste.

* Another layer of cloth strap smeared with the black gram paste is wrapped over this, sealing the junction of rexin and skin layer.

* The medicated Dhanvantaram tailam is warmed to just above body temperature and poured into the vastiputaka with a strip of cloth touching the scalp and oil being poured from the other end or a long piece of coconut leaflet held obliquely inside the vastiputaka $2-3 \mathrm{~cm}$ above the scalp. The oil is filled up to a height of $2-3 \mathrm{~cm}$ above the hair root. To maintain the temperature, some amount of oil should be replaced with warm oil at regular intervals.

* The procedure should continue till secretions through nose, throat and eyes are observed. In case of non attainment of these lakshanas the time should be fixed as 30 minutes for Kapha, 40 minutes for Pitta and 50 minutes for Vata.

* The patient should sit comfortably with eyes closed. Oil in kharapaka is preferred. Temperature of the oil should be just above body temperature.

* During procedure gentle massage to neck and shoulders should be done frequently. Movements of neck should be prevented.

\section{Postoperative procedure:-}

At the end of the procedure, a passage is made above the ear, to remove the oil. Oil over the head must be wiped out with a dry cloth, and abhyanga is done over head, shoulder, palms and soles. Rasnadi choorna is rubbed over the head. Take rest for one hour and then, patient should take bath with lukewarm water..

Duration: 7 -14 days

Quantity: 1.8litre

\section{Results: -}

Observations: - Registered 9 patients completed the treatment schedule successfully; All the patients were suffering from Ischemic stroke. Percentage of Incidence of age of 9 cases of pakshaghata is as 30-40yr age is $11 \%, 50-60 \mathrm{yr}$ age $-44 \%, 60-70 \mathrm{yr}$ age-22\%, 70-80yr age $-11 \%, 80-90 \mathrm{yr}$ age $-11 \%$ all were males. Among 9 Patients 7 were suffering from vama pakshghata, 2 were dakshina pakshaghata. During the study deviation of mouth is seen in one patient only. Vakstambha is seen in 2 patients. In study chronicity of pakshaghata within 1month, 6patients noted. 2 cases were 2 months duration, 1 case was 5yr of chronicity. Roga arambha among them history sudden onset are 8 patients. Stroke during day time are in 5 cases, 4 cases in night time. During nidravastha 2cases, gamana vastha 5 cases, krodavastha 2 cases. samjanasa during stroke is found in 3 cases. During this study it was found that 7 were hypertensive, diabetic 2cases. 3 cases had previous history of pakshaghata attack. 2 patients were found to have similar complaint among family members. In the study 5 patients were alcoholic, 6 were addiction of dhoomapana but later terminated the smoking.

Results were analyzed on the basis of grading of subjective and objective parameters using statistics. The observed grading in the patients on subjective and objective parameters as follows. 


\begin{tabular}{|c|c|c|c|c|c|c|c|c|c|c|c|c|c|c|}
\hline Sl.no & \multicolumn{2}{|c|}{ Walking } & \multicolumn{2}{|c|}{$\begin{array}{l}\text { Lifting of arm } \\
\text { at shoulder }\end{array}$} & \multicolumn{2}{|c|}{$\begin{array}{l}\text { Lifting of } \\
\text { leg at hip } \\
\text { joint }\end{array}$} & \multicolumn{2}{|c|}{ Loss of speech } & \multicolumn{2}{|c|}{$\begin{array}{l}\text { Finger } \\
\text { movement }\end{array}$} & \multicolumn{2}{|c|}{$\begin{array}{l}\text { Tendon } \\
\text { reflex }\end{array}$} & \multicolumn{2}{|c|}{$\begin{array}{l}\text { Muscle } \\
\text { power } \\
\text { grading }\end{array}$} \\
\hline 1 & 1 & 3 & 0 & 1 & 1 & 1 & 2 & 1 & 2 & 3 & 0 & 1 & 0 & 3 \\
\hline 2 & 1 & 4 & 0 & 3 & 0 & 1 & 3 & 0 & 0 & 3 & 0 & 0 & 1 & 4 \\
\hline 3 & 1 & 3 & 0 & 3 & 0 & 1 & 3 & 1 & 1 & 2 & 0 & 1 & 1 & 2 \\
\hline 4 & 1 & 2 & 0 & 1 & 0 & 1 & 4 & 1 & 1 & 2 & 0 & 1 & 0 & 2 \\
\hline 5 & 2 & 4 & 0 & 2 & 0 & 2 & 4 & 1 & 1 & 3 & 0 & 2 & 0 & 3 \\
\hline 6 & 1 & 4 & 0 & 4 & 0 & 2 & 3 & 1 & 1 & 3 & 1 & 3 & 1 & 4 \\
\hline 7 & 1 & 3 & 0 & 2 & 0 & 1 & 3 & 1 & 1 & 3 & 1 & 2 & 0 & 3 \\
\hline 8 & 0 & 3 & 0 & 0 & 0 & 1 & 4 & 1 & 0 & 1 & 0 & 1 & 0 & 2 \\
\hline 9 & 1 & 4 & 1 & 3 & 1 & 2 & 3 & 0 & 1 & 3 & 1 & 2 & 1 & 4 \\
\hline
\end{tabular}

\section{Overall effect:-}

Over all result of shirovasthi therapy is $78 \%$ in Pakshaghata. By observations it is noted that on walking it has shown $70 \%$ on, lifting of arm at shoulder $94 \%$, on lifting of leg at hip joint $83 \%$, on loss of speech $76 \%$, on finger movement $65 \%$ improvement seen .on Tendon reflexes $76 \%$ and on muscle power it has shown $85 \%$ improvement. Marked improvement in 7 patients, moderate improvement in 2 patients, no poor improvement is seen during study.

\section{Discussion:-}

Role of Poorvakarma: Sneha sweda accomplishes mrudutva at the site of origin of vata which facilitates restoration of vata to normalcy. The Absorption of swedas makes the Mastishka dhatu and dhamanis get softened causing alleviation of stabdhata \& sosha resulting into mastishka dhamani vikara, as a result normal supply of rakta takes place to Mastishka making the restoration function of the mastishka dhatu.

\section{Mode of Action Of Shiro Vasthi:-}

The mode of action of shirovasthi depends on. Therapeutic effect of shirovasthi, Physical effect of shirovasthi and Application of heat. The scalp is formed by five layers, Skin, Connective tissue, Aponeurosis, Loose areolar layer and Pericrainium. The dense subcutaneous connective tissue has the richest cutaneous blood supply in the body. The base of medicine which is used for shirovasthi is in lipid form. The phospholipids of the cell membrane allows lipid soluble medications to pass through circulation which gives local and systemic therapeutic actions as vasodilatation will increase due to the temperature which is maintained during the course of entire treatment.

Since the scalp is supplied with rich blood circulation via branches of external carotid and internal carotid arteries and innervations is through sensory and motor nerves from ophthalmic divisions like Zygomaticotemporal nerve, Greater occipital nerve, Lesser occipital nerve, Auriculotemporal nerve, Supratrochlear nerve and Supraorbital nerve and rich lymphatic channels. The medicines which are used in shirovasthi will be having pharmacological actions like anti-inflammatory, antioxidants, anti depressents, neuropyscho pharmacological effect, neuroprotective activity, antimicrobial properties, will show its Therapeutically actions when these enter in the circulation.

When an individual sits in a relaxed state for longer time, Tamasika Guna overcomes the Rajasika Guna. The procedure of shirovasthi brings the Sanjnavaha Srotas in peaceful state and in rest which helps in inducing sleep. The warm oil used for the shirovasthi sub sides Vata Dosha and quantity of Taila may increase the Kapha Dosha. It may also increase Tamoguna in the Sirah Pradesha. Hence it helps in inducing the sleep. Shirovasthi has been reported to be having an excellent result on such disorders as it gives strength to the central nervous system. It calms down both the mind and the senses which allow the body's natural healing mechanism to release stress from the nervous system by pacifying Vata dosha, particularly Prana vayu. Shirovasthi is a snigdha sweda yukta procedure i.e., it has dual benefits of both Snehana and Swedana. The temperature of the taila \& ghrita in shirovasthi, leads to peripheral vasodilatation. This increases the peripheral circulation which nourishes the tissues, hastens phagocytosis and brings about regenerative changes. The neurotransmitters released during this period improve the afferent and efferent pathways and eventually the tonicity of muscles affected get improved. 
During the age, 50-60 years, prokapa of vata dosha starts thus incidence of pakshaghata is more in this age group as pakshaghata is one of the vatavyadhi. Predominance of male patient's observation correlates with the modern textual observation regarding higher prevalence of male than females. Most of the patients were found labors. As per our classics, as these people are indulging in ativyayama, they are prone to Vataprakopa and hence vatavyadhi like Pakshaghata.

The Dominant site that is usually the Left side of the brain especially parietal \& temporal lobes control more vital functions than the right. calculation, planned, movements, appreciation of size, shape, weight, texture are the function of dominant site of parietal lobe, speech, language, verbal memory are the special function of dominant temporal lobe. Any obstruction to the cerebral perfusion to these vital centers can give rise to ischemia \& infraction.

Only Hypertension in 7patients, only Diabetes in 2 patients, Both Hypertension and Diabetes are observed in 2patients. Stroke may results from cerebral hemorrhage or cerebral infraction and is a common complication of hypertension and major cause of death in Hypertensive patients. The next risk factor after hypertension is Diabetes.

In the clinical study it is observed that, 5 patients were habituated to madyapana. Madya possess Kashaya, tikta, katu, amlaras, amla vipaka \& laghu, ushna gunas with its katu, tikta, kashaya rasas \& laghu gunas aggravates Vata; with its Amla,katu rasa,ushna,tikshna gunas it even aggravates pitta dosha. As Kashaya rasa adhika sevana is the specific nidana factor for Pakshaghata,it aggravates vata and incorporates stambhana, lekhana, shoshana and kledopashoshana gunas in the body. Hence becomes the causative factors for the disease. According to Modern system of medicine high alcohol intake is the risk factor for stroke. Cerebral haemorrhage, dementia, cerebellar degeneration etc., are the physical effects of alcohol abuse.

The Patients addicted to Dhoomapana were 6 in number. The Dhoomapana gunas are Ushna, tikshna, ruksha, laghu gunas. These gunas vitiate Vata and also Pitta. Smoking is the risk factor in stroke. It is responsible for Hypertension, M.I. These are the aetiological factor for stroke.

The Chronicity ranging more than 1year not responded well for the therapy but wherein chronicity is less than 1week patients had marked relief of symptoms. Hence it revealed that early onset of stroke cases had good improvement than older ones for treatment.

\section{Conclusion:-}

Shirovasthi is a type of moordha taila. Chronologically sirovasthi, pichu, siroseka, siroabhyanga are less potent each other in order. Sirovasthi particular for Pakshaghata in general for vata disorders is indicated by sushruta, after performing sneha, sweda. Tailam having vatahara property will be directly reaching the site of lesion of pakshaghata. Tailam used is Dhanvantaram tailam which is unique remedy for Vata vyadhi. Pakshaghata is such a disease caused predominately by vata dosha even though all the three doshas. Sneha, sweda karma will be very useful in pakshaghata. In Shirovasthi both sneha, sweda are done simultaneously.

In such diseased condition, it is important to improve the quality of life of the patient, and exactly this is done by the present study. An attempt had been made to study the effect of Shirovasthi in management of Pakshaghata. Approximately half of patients were recovered completely. Remaining half were left with persistent disability or deformity. The treatment has shown encouraging effect on functional deformity. Considering the deep seated nature of disease, its chronicity, involvement of main marma (sira), longer duration of therapy is required. Here it is mandatory to continue the treatment for few more sittings to get better results.

\section{References:-}

1. llustrated Sushrutha samhita by prof. Srikantha murthy - cikitsa sthana $5^{\text {th }}$ chapter, $19^{\text {th }}$ shloka, Varanasi, chowkhambha oriental's series -2016 page no:71.

2. Vagbhata's Ashtanga hrudayam by prof. Srikantha murthy- sutrasthana 22/27-31 Varanasi, chowkhambha oriental's series 2014,pg.no: 274

3. Chikitsa sangraha by P.S. Varier

4. Harrison's internal medicine

5. http://healingearth.co.in/shiro-vasti/

6. http://www.vishwaayurveda.org/jvap_ cited on may_Jun_2014.pdf 